\title{
ACUTE PANCREATITIS ASSOCIATED TO THE USE OF VALPROIC ACID
}

\author{
José Guevara-Campos', Lucía González-Guevara², Ixora Vacaro-Bolívar ${ }^{3}$, Juan Manuel Rojas ${ }^{4}$
}

The first case of pancreatitis associated to the use of valproic acid was reported by Batalden et al in 1979'. In Latin America, the first case of acute pancreatitis due to the use of valproic acid was reported in Brazil in $1986^{2}$. The incidence of pancreatitis following the use of drugs varies between $2-15 \%$ among the general population ${ }^{3-5}$. In medical literature, by 2005,80 cases of acute pancreatitis caused by valproic acid were reported, 33 of which were patients under the age of $18^{6}$. Acute pancreatitis due to valproic acid may be an idiosyncratic complication unrelated to the patient's age, the duration of the treatment and the dose of the drug $\mathrm{g}^{7-9}$. The idiosyncratic complications associated to valproic acid may be hematological, the most common one being thrombocytopenia and hepatic complications that may lead to fulminating hepatitis and acute pancreatitis, which may become a type of hemorrhagic necro$\operatorname{sis}^{10-12}$. One of the possible causes that trigger pancreatitis is the direct toxic effect produced by free radicals on the pancreas ${ }^{8}$. It has also been suggested that the reduction of carnitine brought about by the use of valproic acid has an important role in the damage caused to the pancreas ${ }^{13}$.

The diagnosis of pancreatitis is made by means of the clinical signs and symptoms, among which stand out abdominal pain localized in the epigastrium, nausea that may be attended by vomiting, abdominal distension, fever and malaise ${ }^{14}$. The determination of blood amylase and lipase levels is fundamental, as their increase helps to orient us and may confirm the clinical suspicion. Amylase levels may increase in some patients receiving valproic acid without turning into pancreatitis ${ }^{15}$. In a patient receiving valproic acid, a diagnosis of pancreatitis must be established with increased levels of pancreatic enzymes together with the presence of clinical symptoms. The increase of lipase, which is secreted only by the pancreas, is a more specific indication of pancreatic damage. Amylase may be produced by other tissues, such as the salivary glands ${ }^{16}$. The withdrawal of the drug in a child sus- pected of having pancreatitis who is being administered valproic acid is mandatory; and once it is confirmed, the drug may not be administered again due to the high incidence of relapse leading to death ${ }^{17}$.

We alert pediatricians and neuropediatricians to consider pancreatitis when a child receiving treatment with valproic acid shows gastrointestinal symptoms, as it is a complication that may be difficult to diagnosis.

\section{CASE}

A 7-year old girl with a generalized epilepsy (absence seizure), being treated with valproic acid with a dose of $15 \mathrm{mg} / \mathrm{kg} /$ day, administered in two doses every twelve hours, since one year. She was brought to consult because she had abdominal pain localized in the epigastrium, medium intensity, which was not alleviated by the administration of common antispasmodic type analgesics; concomitantly she had a $38.5^{\circ} \mathrm{C}$ fever, for which she was hospitalized.

She was the term product of a fifth pregnancy mother resulting from a non-consanguineous relationship. The delivery was normal. Her Apgar scores were 7 at 1 minute, 9 at 5 and 10 minutes. Birth weight: $2.100 \mathrm{Kg}\left(<10^{\text {th }}\right.$ percentile). Height at birth: $45 \mathrm{~cm}\left(<10^{\text {th }}\right.$ percentile).

There was not family history of epilepsy, migraine or neurological disease.

On physical examination - Weight: $29 \mathrm{Kg}\left(90^{\text {th }}\right.$ percentile). Height: $150 \mathrm{~cm}$ ( $>97^{\text {th }}$ percentile). Head circumference: $52 \mathrm{~cm}$ ( $>50^{\text {th }}$ percentile).

Regular general condition, feverish, hydrated. No dysmorphic features or cutaneous blemishes were observed.

There were no cranial nerve palsies and pupils reacting equally. Deep tendon reflexes were normal. Respiratory and cardiovascular systems were normal.

The abdomen was soft and depressible, with pain upon deep palpation at the epigastrium. No masses or hepatosplenomegaly was palpable and bowel sounds were present. The remainder of the examination was normal.

\section{PANCREATITE AGUDA ASSOCIADA AO USO DE ÁCIDO VALPROICO}

'Neuropediatrician, Pediatrics Service of the Hospital “Felipe Guevara Rojas”, El Tigre-Anzoátegui, Venezuela; ${ }^{2}$ Pediatrician, Electroencephalographer, Epilepsy and Encephalography Unit,Clinical Center "Esperanza Paraco", El Tigre-Anzoátegui, Venezuela; ${ }^{3 P e d i a t r i c s ~ R e s i d e n t, ~ P e d i a t r i c s ~ S e r v i c e ~ o f ~ t h e ~}$ Hospital "Felipe Guevara Rojas “, El Tigre-Anzoátegui, Venezuela; ${ }^{4}$ Pediatrician, Pediatrics Service of the Hospital “Felipe Guevara Rojas”, El TigreAnzoátegui, Venezuela.

Received 25 August 2008, received in final form 7 January 2009. Accepted 1 April 2009.

Dr. José Guevara-Campos - Calle 26 Sur, Qta. "Sinamaica” - El Tigre - Edo Anzoátegui, 6034 - Venezuela. E-mail: joguevara90@hotmail.com. 


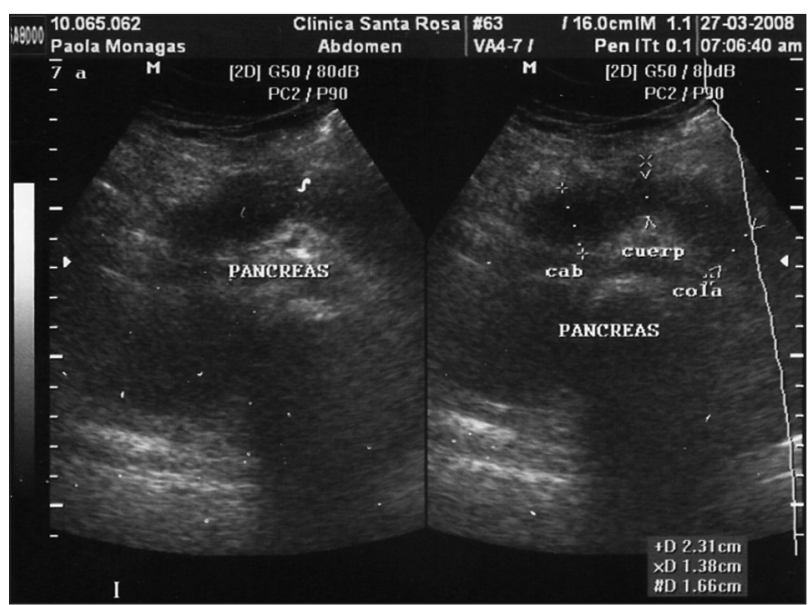

Figure. An ultrasound of pancreas in a plane transverse to a frequency of 3.5 MHZ showed an enlarged pancreas with a normal morphology and measures for increased patient age.

Laboratory tests showed the following results: Hemoglobin: $13.1 \mathrm{~g} / \mathrm{dL}$; Hematocrit: $41.2 \%$; platelets: $225,000 \mathrm{~mm}^{3}$; Leucocytes: $10,700 \mathrm{~mm}^{3}, 65 \%$ neutrophiles and $35 \%$ lymphocytes. Glucose: $109 \mathrm{mg} / \mathrm{dL}$. Liver and kidney function tests were normal.

Valproic acid levels: $70 \mu \mathrm{g} / \mathrm{ml}$ (therapeutic range: $50-100$ $\mu \mathrm{g} / \mathrm{ml})$.

The concentration of serum electrolytes was: Sodium: 148 $\mathrm{mEq} / \mathrm{L}$, Potassium: $3.58 \mathrm{mEq} / \mathrm{L}$.

The determination of pancreatic enzymes revealed that serum amylase had increased to $400 \mathrm{U} / \mathrm{L}$ (Normal values: 20$112 \mathrm{U} / \mathrm{L})$.

Abdominal ultrasonography revealed a morphologically normal pancreas; with considerably enlarged. There were no peripancreatic fluid collections and no biliary dilatation. The head measured $2.31 \mathrm{~cm}$, the body $1.38 \mathrm{~cm}$ and the tail $1.66 \mathrm{~cm}$, pancreatic duct with diameter $2.2 \mathrm{~mm}$ (Figure).

Normal pancreas size as a function of age (Ultrasound) 5 to 10 years are head in $\mathrm{cm}(1.6 \pm 0.4)$, body ( $1 \pm 0.3)$, tail $(1.8 \pm 0.4)$ on transverse scan. The normal pancreatic duct is less than $2 \mathrm{~mm}$ in diameter

An EEG interictal revealed generalized spike and wave activity intermittent with a frequency of $3 \mathrm{~Hz}$, bilateral and synchronous, during hyperventilation, with two seconds of duration.

An abdominal computed axial tomography (CAT) did not show cystic or tumor lesions and confirmed enlargement of the pancreas that was reported by ultrasound.

The result of an amylase determination performed 72 hours after the suspension of valproic acid was $131 \mathrm{U} / \mathrm{L}$, and it became normal on the sixth day after the anti-epileptic drug had been suspended. The patient became asymptomatic.

Anti-epileptic therapy with lamotrigine was begun at a dose of $3 \mathrm{mg} / \mathrm{kg} /$ day, administered in two doses every 12 hours, and was tolerated satisfactorily.

The patient family gave informed consent for the pulication of the case.

\section{DISCUSSION}

Valproic acid is the most widely used anti-epileptic drug in children, and it is probably the most frequent cause of drug-induced acute pancreatitis. The mechanism whereby valproic acid induces pancreatitis is unknown. Valproic acid is metabolized in the liver in the pathways of microsomal glucuronidation, mitochondrial oxidation, and by cytochrome P 450 that depend on omega oxidation, the result being at least five metabolites. Two important metabolites are: 2-valproic acid, which is the active pharmacological metabolite, and 4-valproic acid, which may be involved in toxicity ${ }^{18}$.

Several researchers have proposed that valproic acid causes a reduction of superoxide dismutase, catalase, and glutathione peroxidase, which are in charge of removing free radicals. The increase of free radicals can lead to an increase of endothelial permeability and lipid peroxidation, leading to tissue damage which in turn causes hepatoxicity and pancreatitis ${ }^{19}$.

Abdominal pain is the most frequent symptom of acute pancreatitis, and it occurs in more than $80 \%$ of patients localized in the epigastrium, as happened with our patient. It can also be accompanied by nausea and vomiting in $70 \%$, abdominal distension in $30 \%$, and fever in $26 \%$ of the cases described ${ }^{15}$.

There are no reliable and sensible clinical criteria to objectively assess the gravity and the prognosis in children $^{20}$. The determination of the levels of lipase and the pancreatic isoenzyme amylase is essential to corroborate clinical diagnosis ${ }^{15,21}$. Lipase is an enzyme that is only secreted by the pancreas, and its increase is a specific indicator of pancreatic damage ${ }^{16}$. Amylase is not an enzyme exclusive to the pancreas; other glands, such as the salivary glands, secrete it as well and may be responsible for its increase. Therefore, the determination of pancreatic and salivary amylase isoenzymes can be useful to confirm a diagnosis of pancreatitis. We did not perform the determination of either lipase or pancreatic amylase isoenzyme; nevertheless, the clinical picture, the increase of amylase to $400 \mathrm{U} / \mathrm{L}$ and echography studies, allowed us to reach a diagnosis.

Abdominal ultrasonography imaging showed the pancreas to be considerably enlarged, as has been reported by other authors ${ }^{20}$.

An ultrasound is useful at the preliminary evaluation of patients suspected of having acute pancreatitis, and it must be done within the first 24 to 48 hours from the onset of the clinical symptoms. Thus, ultrasonography of the pancreatic duct is valuable in diagnosis and monitoring of pancreatitis in children ${ }^{22}$.

An abdominal CAT must be performed on every patient with serious acute pancreatitis, as it plays a very important role in the diagnosis to assess the extent of the 
inflammatory process, the presence of macroscopic necrosis and the existence of pseudocysts or tumors, which were not detected in our patient.

The withdrawal of valproic acid permitted the normalization of the amylase levels and the disappearance of the clinical symptomatology, which occurred during the first week, as has been published by other authors ${ }^{15}$.

The use of valproic acid must be avoided in patients who have had acute pancreatitis associated to the use of valproic acid, due to its high relapse rate and complications ${ }^{17}$.

In conclusion, acute pancreatitis must always be considered when a child is under treatment with valproic acid. Finding pancreatic amylase and lipase isoenzymes would confirm the clinical suspicion. The suspension of the administration of valproic acid in patients who have acute pancreatitis is mandatory, and use of the acid must not be resumed once the patient has recovered.

\section{REFERENCES}

1. Batalden PB, Van Dyne BJ, Cloyd P. Pancreatitis associated with valproic acid therapy. Pediatrics 1979;64:520-522.

2. Tannhauser Barros HM, Guardao Barros EJ, Abreu Carvalho JT. Pancreatite aguda associada ao uso de valproato de sodio. Rev Asoc Med Bras 1986;32:33-34.

3. Steinberg W, Terner S. Acute pancreatitis. New Engl J Med 1994;28:1198-1210

4. Stanley CJ, Marvin EA. Pancreatitis in childhood and adolescents. J Pediatr 1998;91:211-216.

5. Wilmink T, Frick TW. Drug induced pancreatitis. Drug Saf 1996;14:406-423.

6. Barreda L, Rosas J, Millan William, Valdivia D, Targarona J. Valproato de sodio como causa de pancreatitis aguda: reporte de un caso. Rev Gastroenterol Perú 2006;26:318-323.

7. Asconapé JJ, Penry JK, Dreifuss FE, Riela A, Mirza W. Valproate-associated pancreatitis. Epilepsia 1993;34:177-183.

8. Pellock JM, Wilder BJ, Deaton R, Sommerville KW. Acute pancreatitis coincident with valproate use: A critical review. Epilepsia 2002;43:1421-1424.

9. Norgaard M, Jacobsen J, Ratanajamit C, et al. Valproic acid and risk of acute pancreatitis: A population-based case control study. Am J Ther 2006;13:113-117.

10. Kriel RL, Cloyd JC. Antiepileptic drug therapy in children: pharmacokinetics, adverse effects and monitoring. In Swaiman KF (Ed). Pediatric Neurology: principles and practice. 3.Ed. St Louis: Mosby, 1999:583-609.

11. Rosenberg HK, Ortega W. Hemorrhagic pancreatitis in a young child following valproic acid therapy: clinical and ultrasonic assessment. Clin Pediatr 1987;26:98-101.

12. Munhoz R, Santos ML, Hernández-Fustes O. Pancreatite necrohemorrágica fatal asociada ao uso de valproato de sódio. Arq Neuropsiquiatr 2001;59:821-823.

13. Moreno FA, Macey H, Schreiber B. Carnitine levels in valproic acid treated psychiatric patients: a cross-sectional study. J Clin Psychiatry 2005;66:555-558.

14. Sinclair DB, Berg M, Breault R. Valproic acid induced pancreatitis in childhood epilepsy: case series and review. J Child Neurol 2004;19:498-502.

15. Werlin S, Fish DL. The spectrum of valproic acid-associated pancreatitis. Pediatrics 2006;118:1660-1663.

16. Hermida Ameijeiras J, Tutor Crespo M J, Tutor Valcarce JC. Lipase and total amylase and its isoenzymes as markers of pancreatic injury in patients treated with antiepileptic drugs. Farm Hosp 2007;31:303-306.

17. Ozaydm E, Yükselgúngór H, Kóse G. Acute hemorrhagic pancreatitis due to the use of valproic in a child. Eur J Paediatr Neurol 2008;12:141-143.

18. Buck ML. Valproic acid in the treatment of pediatric seizures. Pediatrics Pharmacotherapy 1997;3:1-4.

19. Holland K. Efficacy pharmacology and adverse effects of antiepileptic drugs. Neurologic Clin 2001;19:26-35.

20. Otusbo S, Huruzono T, Kobae H. Pancreatitis with normal serum amylase associated with sodium valproate. Brain Dev 1995;17:219-221.

21. Haber PS, Pirola RC, Wilson JS: Clinical update management of acute pancreatitis. J Gastroenterol Hepatol 1997;12: 189-197.

22. Siegel MJ, Martin KW, Worthington JL .Normal and abnormal pancreas in children: US studies. Radiology 1987;165:15-18. 